\title{
Growth of Leucaena leucocephala (Lam.) de Wit favored by organic waste in the Brazilian semiarid region
}

\author{
Francisco H. C. Amaral ${ }^{1}$, Júlio C. A. Nóbrega ${ }^{2}$, Rafaela S. A. Nóbrega ${ }^{2}$, \\ José F. Lustosa Filho ${ }^{1} \&$ Sarah P. do N. Amorim ${ }^{3}$ \\ ${ }^{1}$ Universidade Federal de Lavras/Departamento de Ciência do Solo. Lavras, MG. E-mail: helcioagro@gmail.com (Corresponding author); filhoze04@hotmail.com \\ ${ }^{2}$ Universidade Federal do Recôncavo da Bahia/Centro de Ciências Agrárias, Ambientais e Biológicas. Cruz das Almas, BA. E-mail: juliocnobrega@gmail.com; \\ rafaela.nobrega@gmail.com \\ ${ }^{3}$ Universidade Federal do Piauí/Campos Professora Cinobelina Elvas. Bom Jesus, PI. E-mail: amorimspn@gmail.com
}

\section{Key words:}

substrates

seedling quality

recovery of degraded areas

\begin{abstract}
A B S T R A C T
The aim of this study was to evaluate the effect of sources and rates of organic waste and their interaction on the growth of Leucaena leucocephala (Lam.) de Wit, in the Southeast region of Piauí State. The treatments consisted of two sources (Copernicia prunifera (Mill.) H.E. palm residue and plant compound) and six organic waste rates. The study was conducted in the period of March-June 2011 and the following parameters were evaluated: stem diameter, height, number of leaves, shoot dry weight, root dry weight, total dry matter, root volume, shoot dry weight/root dry weight ratio, height/stem diameter ratio and the Dickson Quality Index. The Copernicia prunifera (Mill.) H.E. palm residue and plant compound showed a great potential to be used in the manufacture of substrates for the production of seedlings Leucaena leucocephala (Lam.) de Wit, since their initial development was influenced by the sources and proportions of these organic residues and by the interaction between these treatments. The substrate containing $50 \%$ of plant compound produced better quality of plants of Leucaena leucocephala (Lam.) de Wit in their initial development stage.
\end{abstract}

\section{Palavras-chave:}

substratos

qualidade de mudas

recuperação de áreas degradadas

\section{Crescimento de Leucaena leucocephala (Lam.) de Wit favorecido por resíduos orgânicos no semiárido brasileiro}

\section{R E S U M O}

O objetivo deste estudo foi avaliar o efeito de fontes, proporções de resíduos orgânicos e da sua interação no crescimento de mudas de Leucaena leucocephala (Lam.) de Wit, na região Sudeste do estado do Piauí. Os tratamentos foram constituídos de duas fontes (resíduo de palha de Copernicia prunifera (Mill.) H.E. e composto de plantas) e seis proporções de resíduo orgânico. O estudo foi conduzido no período de março a junho de 2011 e foram avaliadas as seguintes variáveis: diâmetro de caule, altura, número de folhas, massa seca de parte aérea, massa seca de raiz, massa seca total, volume de raiz, relação massa seca de parte aérea/massa seca de raiz, razão altura/diâmetro de caule e o Índice de Qualidade de Dickson. Os resíduos de palha de Copernicia prunifera (Mill.) H.E. e de composto de vegetal apresentaram grande potencial para serem utilizados na confecção de substrato para produção de mudas de Leucaena leucocephala (Lam.) de Wit uma vez que o desenvolvimento inicial das plantas foi influenciado pelas fontes e pelas proporções desses resíduos e pela interação entre tais tratamentos. O substrato de cultivo contendo $50 \%$ do composto vegetal proporcionou melhor qualidade às plantas de Leucaena leucocephala (Lam.) de Wit na fase inicial de desenvolvimento. 


\section{INTRODUCTION}

The advance of erosion processes in the Brazilian semiarid region covers some states in the Northeast and has contributed to the expansion of desertified areas. In the State of Piauí, soils affected by erosion, which characterize desertification hotspots, already occupy more than $8,000 \mathrm{~km}^{2}$. Since they are located in the semiarid region, the growth and development of vegetation is very limited in this environment, making the reduction and stabilization of erosion processes more difficult, resulting in the expansion of desertified areas in the region. Thus, the use of plant species able to grow in harsh climates may be the most viable alternative for the recovery of desertified areas. However, the success of this practice depends mainly on the species and the initial quality of plants to be grown.

In environments with limitations to plant establishment, growth and development, species tolerant to water stress with fast initial growth should be grown. Among the plant species with such characteristics, it is possible to mention Leucaena leucocephala (Lam.) de Wit, which has been used in the recovery of degraded areas, as a result of its high capacity to adapt to different soil types and tolerance to climatic variations (Lins et al., 2007). Additionally, Leucaena leucocephala (Lam.) de Wit has a good ability to develop a vegetation cover, even in the driest times of the year, which contributes to the increase in soil protection against water and wind erosion. The survival potential of the plant species in the field largely depends on seedling quality, which is higher when the seedlings are formed on substrates favorable to the initial development of the plants. A substrate suitable to the formation of high-quality seedlings should have a high water-holding capacity and nutrient availability to plants (Cunha et al., 2006), as well as a uniform composition and accessible economic costs (Dantas et al., 2009).

Traditionally, seedling production has been performed using substrates made of organic materials, minerals or a combination of both (Caldeira et al., 2008), and the choice of substrate is made by technical and economic criteria. Due to the high availability and low cost (Cunha et al., 2006), the use of organic waste, combined with mineral materials in the preparation of substrates, is an economically viable alternative for the production of tree seedlings, as reported by some studies (Artur et al., 2007; Caldeira et al., 2008; Nóbrega et al., 2008; 2010; Dantas et al., 2009; Paiva Sobrinho et al., 2010). The presence of organic material in the composition of the substrates is essential to ensure water retention and nutrient supply during the initial development of the plant (Paiva Sobrinho et al., 2010).

The aim of this study was to evaluate the effect of sources and rates of organic waste and their interaction on the growth of Leucaena leucocephala (Lam.) de Wit, in the Southeast region of Piauí State.

\section{MATerial AND Methods}

The experiment was conducted in the period of March-June 2011 in a greenhouse, in the seedling manufacturing sector of Federal University of Piauí, Campus of Bom Jesus, located in the municipality of Bom Jesus, PI, Brazil (09 04' 28”' S; 44 $21^{\prime} 31$ " W; $297 \mathrm{~m}$ ). The climate in the region is hot semiarid tropical (Köppen, 1931), with mean annual temperature of $26.5^{\circ} \mathrm{C}$ and mean precipitation of $900 \mathrm{~mm}$ (Viana et al., 2002).

The experimental design was completely randomized, arranged in a $2 \times 5$ (two residues $\mathrm{x}$ six rates) factorial scheme, with five replicates. The treatments consisted of two organic waste sources (Copernicia prunifera (Mill.) H.E. palm residue and plant compound) and six rates of each residue $(0,20$, 40, 60, 80 and 100\%). Copernicia prunifera (Mill.) H.E. palm residue is an agroindustrial remnant obtained by the extraction of the wax powder present on the Copernicia prunifera (Mill.) H.E. palm [C. prunifera (Mill.) H.E. Moore] leaves. The plant compound was obtained from the composting of plant residues coming from pruned trees in the urban area. For the preparation of the rates of each substrate, a soil classified as Quartzarenic Neosol (SiBCS, 2013), collected at $0.50 \mathrm{~m}$ depth, was used. The chemical characteristics of the organic waste and soil used in the preparation of substrates are described in Table 1.

The plant species used in the study was Leucaena leucocephala (Lam.) de Wit, and its propagation was made via certified commercial seeds. Before sowing, it was necessary to overcome seed dormancy, using the technique of chemical scarification, according to the methodology described by Teles et al. (2000). Sowing was performed directly in polyethylene containers (bags with dimensions of $0.15 \times 0.25 \mathrm{~m} \mathrm{x} 0.15 \mathrm{~mm}$ ); four seeds were distributed into each container at a depth of $1.5 \mathrm{~cm}$ from the substrate surface. The moisture of the substrates during the study was maintained at approximately $60 \%$ of the total pore volume, by surface irrigation. Fifteen days after the emergence of the plants, thinning was performed, and only the most vigorous plant, located closer to the center of each container, was left.

At the end of the growing period (75 days after plant germination), the following parameters were evaluated: stem diameter (D. Stem), height and number of leaves (No. of leaves). The plants were then cut and dried in a forced-air oven at a temperature of $60{ }^{\circ} \mathrm{C}$, until constant weight, for the determination of shoot dry weight (SDW), root dry weight (RDW), total dry matter (TDM), root volume (V. Root), shoot dry weight/root dry weight ratio (SDW/RDW), height/stem diameter ratio (Height/D. Stem) and Dickson quality index (DQI).

The results were submitted to analysis of variance, in order to verify the existence of significant differences between sources

Table 1. Chemical characteristics of the materials used in the composition of the substrates

\begin{tabular}{ccccc}
\hline \multirow{2}{*}{ Nutrients } & \multicolumn{4}{c}{ Materials used in the preparation of the substrates } \\
\cline { 2 - 5 } & Unit & Soil & $\begin{array}{c}\text { C. prunifera (Mill.) } \\
\text { H.E. palm residue }\end{array}$ & $\begin{array}{c}\text { Plant } \\
\text { compound }\end{array}$ \\
$\mathrm{nyyyy}$ & $\mathrm{g} \mathrm{kg}^{-1}$ & - & 23.3 & 29.5 \\
$\mathrm{P}$ & $\mathrm{mg} \mathrm{dm}^{-3}$ & 12.4 & 3.6 & 6.6 \\
$\mathrm{~K}$ & $\mathrm{mg} \mathrm{dm}^{-3}$ & 78.0 & 4.0 & 6.0 \\
$\mathrm{Ca}$ & $\mathrm{Cmol}_{\mathrm{c} \mathrm{dm}}^{-3}$ & 1.2 & 4.8 & 32.2 \\
$\mathrm{Mg}$ & $\mathrm{Cmol} \mathrm{dm}_{\mathrm{c}}^{-3}$ & 0.4 & 1.8 & 4.7 \\
$\mathrm{~B}$ & $\mathrm{mg} \mathrm{dm}^{-3}$ & 0.3 & 99.3 & 121.0 \\
$\mathrm{Cu}$ & $\mathrm{mg} \mathrm{dm}^{-3}$ & 0.2 & 8.3 & 25.4 \\
$\mathrm{Fe}$ & $\mathrm{mg} \mathrm{dm}^{-3}$ & 8.4 & $1,096.8$ & $1,035.8$ \\
$\mathrm{Mn}$ & $\mathrm{mg} \mathrm{dm}^{-3}$ & 38.6 & 107.6 & 169.2 \\
$\mathrm{Zn}$ & $\mathrm{mg} \mathrm{dm}^{-3}$ & 1.2 & 28.8 & 94.1 \\
\hline
\end{tabular}


and between ratios of organic waste used in the preparation of substrates, by the F test. Treatment means were compared by the Scott-Knott test, at 0.05 probability level. The variables that showed significant interactions between sources and between ratios of organic waste were subjected to regression testing, and the ratios were split within each organic waste source. All analyses were performed with the aid of the statistical program SISVAR 5.4 (Ferreira, 2014).

\section{Results And Discussion}

The treatments significantly influenced $(\mathrm{P}<0.05)$ all studied variables (Table 2). D. Stem, Height, Number of leaves, SDW, RDW, TDM, V. Root, SDW/RDW, Height/D. Stem and the Dickson quality index were significantly influenced by the interaction between the sources and rates of organic waste $(P$ $<0.05)$. These results indicate that the initial development of Leucaena leucocephala (Lam.) de Wit is directly influenced by the source and rates of organic residue, as well as by the interaction between sources and rates.

D. Stem (Figure 1A), SDW (Figure 1B), height (Figure 1C), and N. of leaves (Figure 1D) responded quadratically to the ratios of organic waste present in the substrates of growing plants. The maximum values of these variables were $6.61 \mathrm{~mm}$ plant $^{-1}$ for D. Stem (61.35\% plant compound), 6.18 g plant $^{-1}$ for SDW (60.78\% plant compound), $83.89 \mathrm{~cm} \mathrm{plant}^{-1}$ for height (66.88\% plant compound) and 17.39 plant $^{-1}$ for No. of leaves (70.57\% plant compound).

Studying different organic compound ratios in the production of Schinus terebinthifolius Raddi seedlings, Caldeira et al. (2008) observed similar results for stem diameter of plants grown on substrates with $60 \%$ organic material in their composition. The results obtained for SDW were similar to those found by Nóbrega et al. (2010) in Trema micrantha (L.) Blumes seedlings, in which $55 \%$ organic waste was used in the preparation of the growth substrate. Height corroborates the results obtained by Nóbrega et al. (2008) in Enterolobium contortisiliquum Vell seedlings grown on substrates consisting of organic waste compost. Araújo \& Paiva Sobrinho (2011) also observed a higher number of leaves in E. contortisiliquum Vell seedlings grown on substrates with approximately $70 \%$ organic material in their composition.

The best results observed for plants grown on substrates that had the plant compound in their composition reflect the greater wealth of nutrients present in this waste (Table 1).
Higher values of D. Stem, SDW, height and number of leaves are quite desirable in the production of seedlings, since these variables are key parameters to estimate the performance, initial growth and survival at the field after planting (Gomes et al., 2003).

RDW (Figure 2A), height/D. Stem (Figure 2B), TDM (Figure 2C) and V. Root (Figure 2D) showed quadratic responses to the addition of plant compound to plant growth substrates. The maximum values observed were $2.54 \mathrm{~g} \mathrm{plant}^{-1}$ for RDW (59.0\% plant compound), 15.88 for Height/D. Stem (89.3\% plant compound), 8.61 g plant $^{-1}$ for SDW (59.5\% plant compound) and $9.12 \mathrm{~cm}^{3}$ plant $^{-1}$ for V. Root (51.5\% plant compound).

Similar values were found by Carvalho Filho et al. (2002) for root dry weight, when studying the production of Cassia grandis L. seedlings in different environments, recipients and substrate mixtures. The Height/D. Stem ratio was greater than that observed by Caldeira et al. (2008), who evaluated organic compound ratios in the preparation of substrates for the production of $S$. terebinthifolius Raddi seedlings. The TDM found in this study corroborates the values obtained by Nóbrega et al. (2008) in T. micrantha (L.) Blumes seedlings grown on substrates with approximately $60 \%$ compost in their composition. Paiva et al. (2011) reported higher V. Roots in Ocimum basilicum L. seedlings grown on substrates with approximately $60 \%$ organic waste in their composition.

The highest SDW/RDW ratio (3.54) was observed for plants grown on substrates with $87.7 \%$ compound in their composition (Figure 3A). On the other hand, plants grown on substrates made up of Copernicia prunifera (Mill.) H.E. palm residue showed a maximum SDW/RDW ratio (2.07) on the substrate with $67.5 \%$ Copernicia prunifera (Mill.) H.E. palm residue in its constitution. This value was similar to those reported by Caldeira et al. (2012) in A. glazioveana Baill seedlings grown on substrates with different ratios of biosolids. Lower SDW/RDW values indicate that the plants were more balanced in the production and distribution of biomass between shoot and root system. Therefore, the ideal is that the seedlings show values close to 2.0 (Brissette, 1984), demonstrating an adequate ratio between the development of root and shoot in seedlings (Barbosa et al., 1997).

The plant compound yielded the highest DQI values in the plants (Figure 3B). The maximum DQI (0.54) was obtained on substrates that had approximately $50 \%$ plant compound in their composition. This DQI value is lower than the values

Table 2. Mean square for stem diameter (D. Stem), height, number of leaves (No. of leaves), shoot dry weight (SDW), root dry weight (RDW), total dry matter (TDM), root volume (V. Root), shoot dry weight/root dry weight ratio (SDW/ RDW), height/stem diameter ratio (Height/D. Stem) and Dickson quality index (DQI), of Leucaena leucocephala (Lam.) de Wit seedlings grown under different sources and ratios of organic waste

\begin{tabular}{|c|c|c|c|c|c|c|c|c|c|c|c|}
\hline \multirow{2}{*}{$\begin{array}{l}\text { Sources } \\
\text { of variation }\end{array}$} & \multirow{2}{*}{ DF } & \multicolumn{10}{|c|}{ Mean squares } \\
\hline & & D. Stem & Height & No. of leaves & SDW & RDW & TDM & V. Root & SDW/RDW & Height/D. Stem & DQI \\
\hline Sources (S) & 1 & 12.06 ** & $23,018.70^{\star * *}$ & $333.33^{\star *}$ & $82.39 * *$ & $3.15^{\star \star}$ & $91.15^{\star \star}$ & $0.37^{\text {ns }}$ & $127.99 * *$ & $562.03^{* *}$ & $0.01^{\mathrm{ns}}$ \\
\hline Rate (R) & 5 & $30.26^{* *}$ & $9,945.11^{\star \star}$ & $215.14^{* *}$ & $76.69 * *$ & $8.51^{* *}$ & $137.57^{\star *}$ & $121.26^{* *}$ & $339.19^{* *}$ & $291.11^{* *}$ & $0.44^{* *}$ \\
\hline$S \times R$ & 5 & $1.62^{\star \star}$ & $1,114.52^{\star \star}$ & $12.03^{* *}$ & $10.26^{\star *}$ & $2.03 * *$ & $16.30^{*}$ & 53.97 ** & 88.06 ** & $23.58 *$ & $0.05^{\star}$ \\
\hline Error & 108 & 0.23 & 11.76 & 0.737 & 0.07 & 0.46 & 0.29 & 1.05 & 65.52 & 1.43 & 0.02 \\
\hline Total & 119 & - & - & - & - & - & - & - & - & - & - \\
\hline CV (\%) & - & 10.29 & 7.59 & 6.92 & 8.17 & 52.11 & 11.73 & 16.04 & 19.96 & 13.26 & 37.86 \\
\hline
\end{tabular}

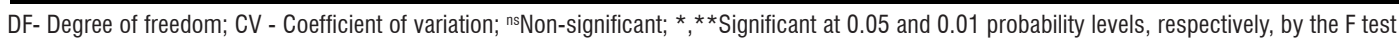


A.

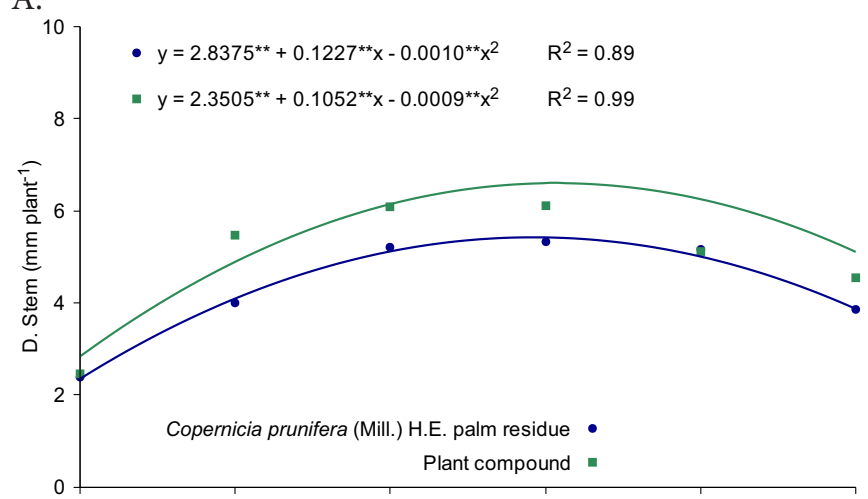

B.

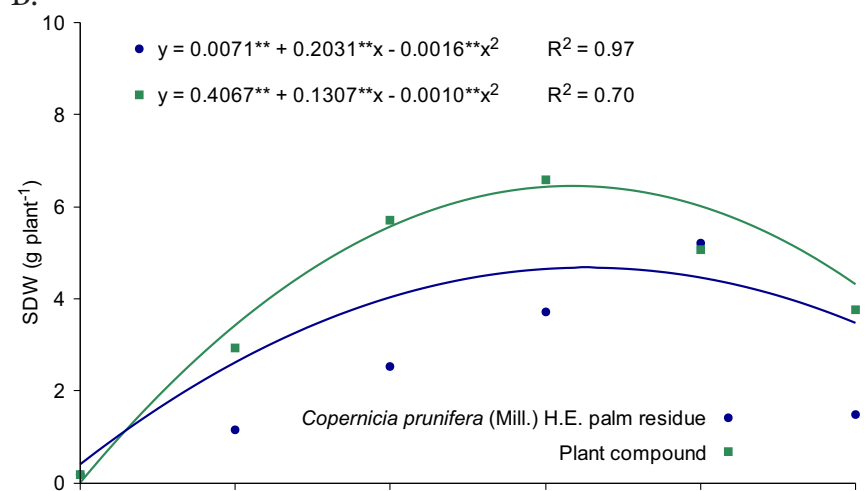

C.

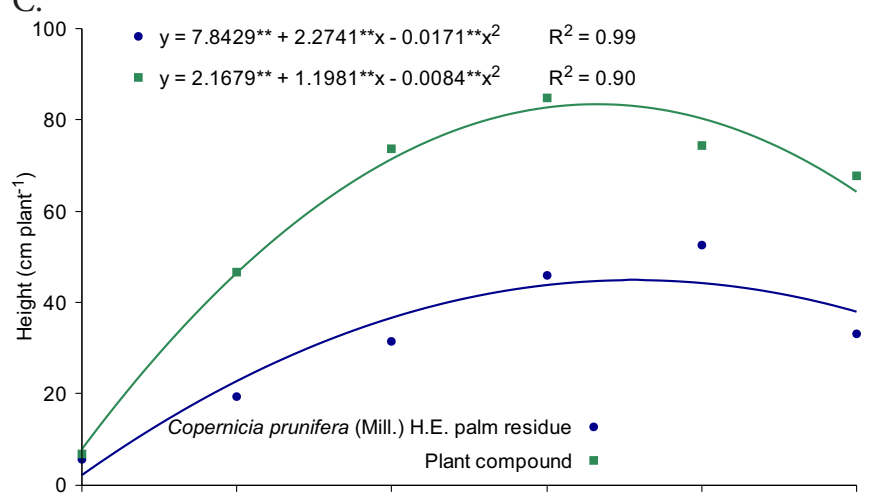

D.

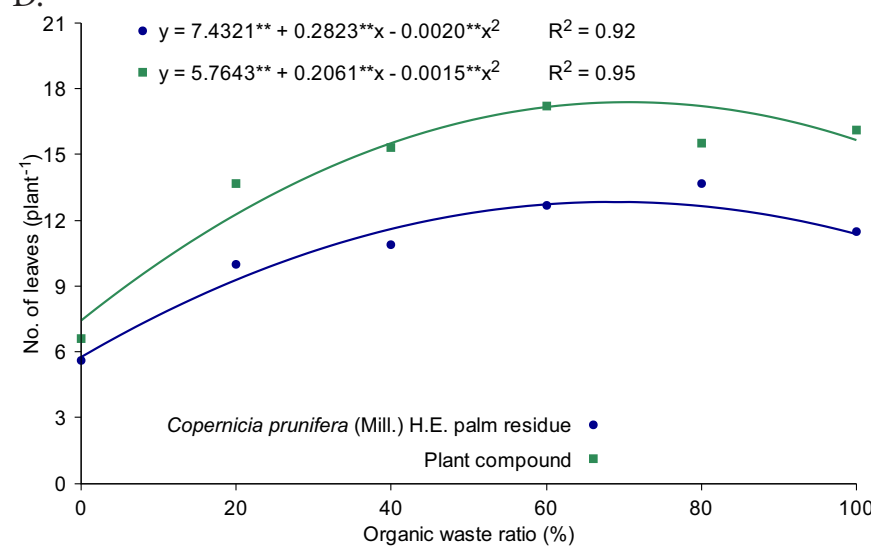

Figure 1. Stem diameter - D. Stem (A), shoot dry weight - SDW (B), height (C) and number of leaves - No. of leaves (D) in Leucaena leucocephala (Lam.) de Wit seedlings grown under different sources and rates of organic waste

obtained by Caldeira et al. (2012) in Ateleia glazioveana Baill seedlings grown on substrates with different ratios of biosolids. However, in the present study, seedlings grown on substrates with $20-80 \%$ organic waste in their composition expressed

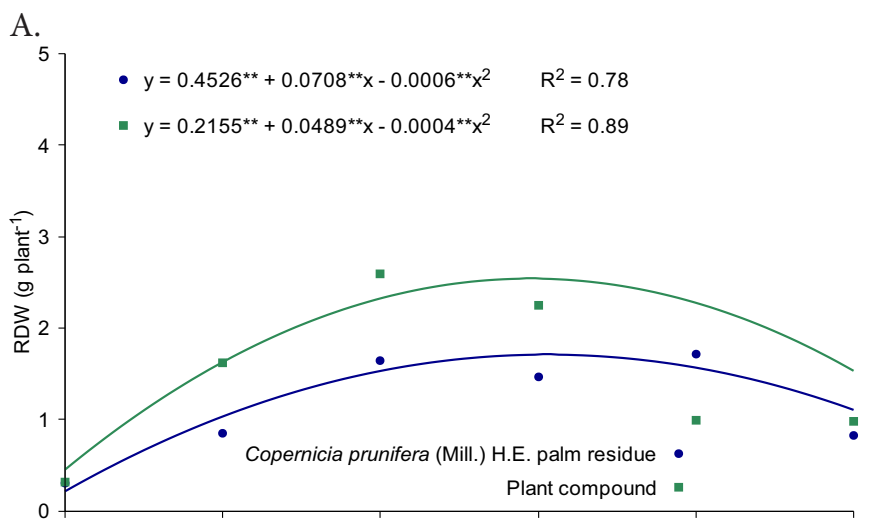

B.

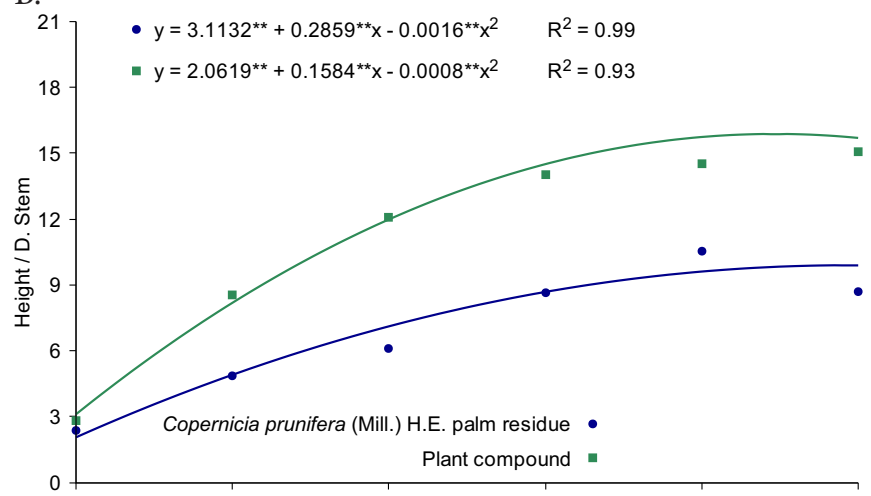

C.

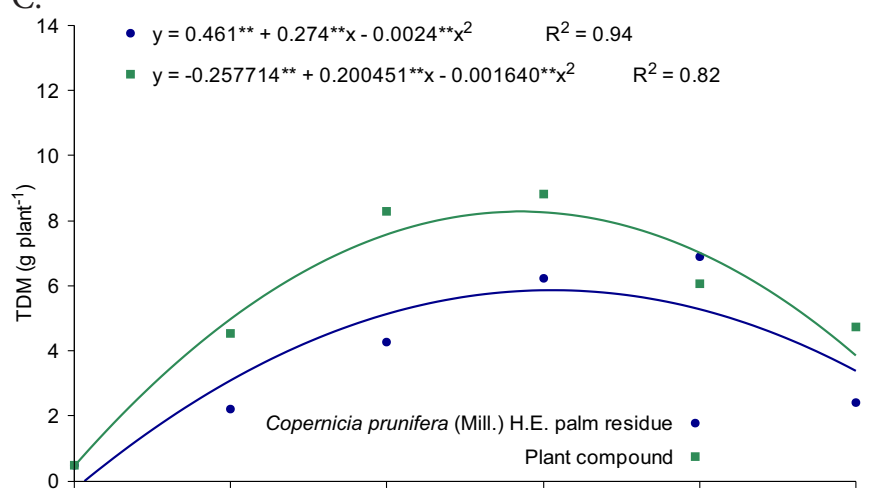

D.

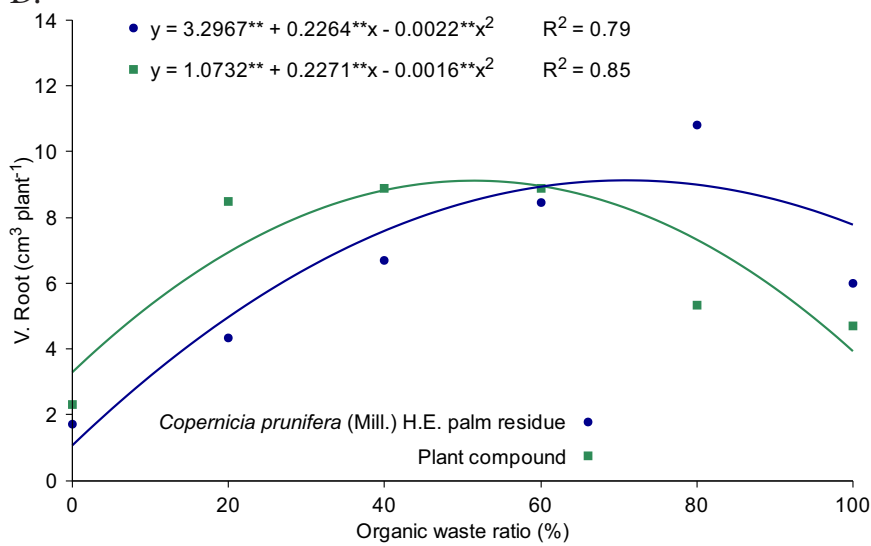

Figure 2. Root dry weight RDW (A), shoot dry weight/root dry weight ratio - Height/D. Stem (B), total dry matter - TDM (C) and root volume - V. Root (D) in Leucaena leucocephala (Lam.) de Wit seedlings grown under different sources and rates of organic waste

DQI values above the minimum established for this parameter, which is 0.20 (Gomes \& Paiva, 2004). According to Bernardino et al. (2005), the higher the value of this index, the better the quality of the seedlings. 
A.

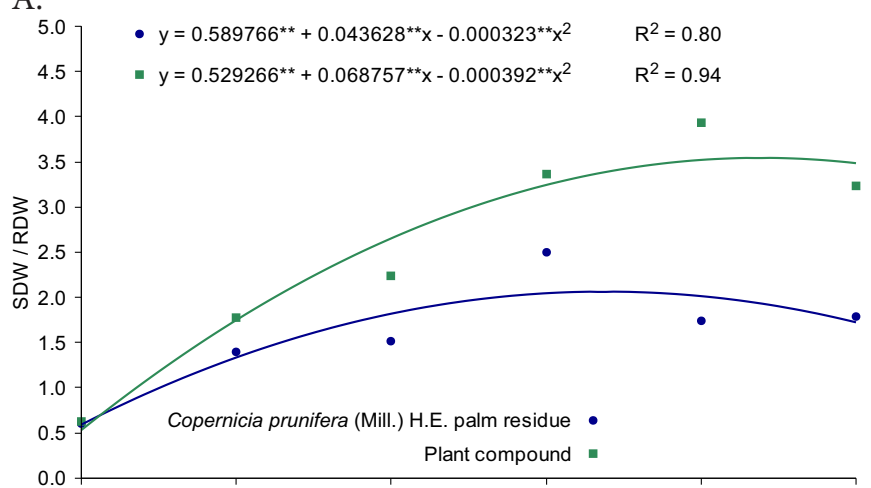

B.

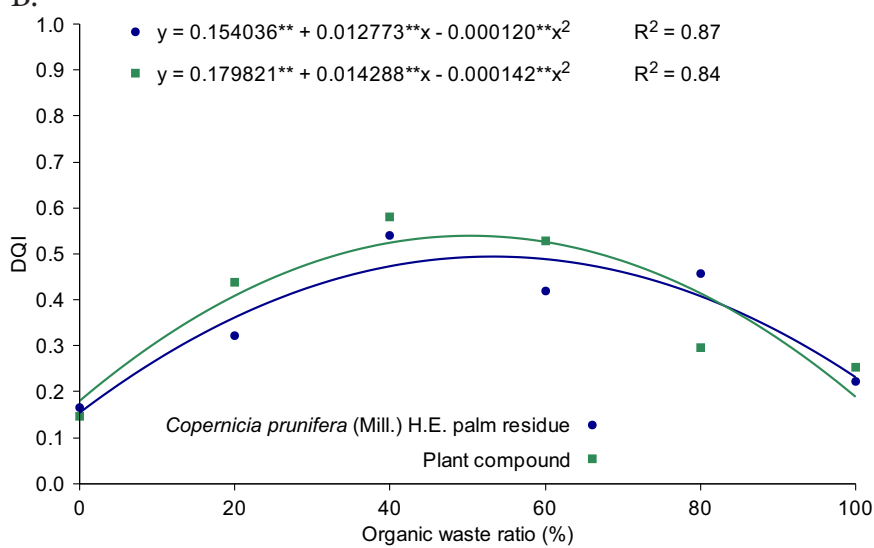

Figure 3. Shoot dry weight/root dry weight ratio - SDW/ RDW (A) and Dickson quality index - DQI (B) in Leucaena leucocephala (Lam.) de Wit seedlings grown under different sources and rates of organic waste

\section{Conclusions}

1. The Copernicia prunifera (Mill.) H.E. palm residue and plant compound showed a great potential to be used in the manufacture of substrates for the production of seedlings of Leucaena leucocephala (Lam.) de Wit, since their initial development was influenced by the sources and rates of these organic residues and by the interaction between these treatments.

2. The substrate containing $50 \%$ plant compound promoted better quality of plants of Leucaena leucocephala (Lam.) de Wit in the initial development stage.

\section{ACKNOWLEDGeMents}

The authors thank the National Council for Scientific and Technological Development [Conselho Nacional de Desenvolvimento Científico e Tecnológico (CNPq)] for the financial assistance.

\section{Literature Cited}

Araújo, A. P. de; Paiva Sobrinho, S. de. Germinação e produção de mudas de tamboril (Enterolobium contortiliquum (Vell.) Morong) em diferentes substratos. Revista Árvore, v.35, p.581-588, 2011. http://dx.doi.org/10.1590/S0100-67622011000400001

Artur, A. G.; Cruz, M. C. P.; Ferreira, M. E.; Barretto, V. C. M.; Yagi, R. Esterco bovino e calagem para formação de mudas de guanandi. Pesquisa Agropecuária Brasileira, v.42, p.843-850, 2007. http:// dx.doi.org/10.1590/S0100-204X2007000600011
Barbosa, Z.; Carvalho. J. G.; Morais A. R. Fósforo e zinco na nutrição e crescimento da aroeira-do-sertão (Myracrodruon urundeuva Fr. All.) I. Características de crescimento das plantas. Ciência e Agrotecnologia, v.21, p.196-204, 1997.

Bernardino, D. C. S.; Paiva, H. N.; Neves, J. C. L.; Gomes, J. M.; Marques, V. B. Crescimento e qualidade de mudas de Anadenanthera macrocarpa (Benth.) Brenan em resposta à saturação por bases do substrato. Revista Árvore, v.29, p.863-870, 2005. http://dx.doi. org/10.1590/S0100-67622005000600004

Brissette, J. C. Summary of discussions about seedling quality. In: Southern nursery conferences. Alexandria: Forest Service, 1984. p.127-128.

Caldeira, M. V. W.; Peroni, L.; Gomes, D. R.; Delarmelina, W. M.; Trazzi, P. A. Diferentes proporções de biossólidos na composição de substratos para a produção de mudas de timbó (Ateleia glazioveana Baill). Scientia Forestalis, v.40, p.15-22, 2012.

Caldeira, M. V. W.; Rosa, G. N.; Fenillt, T. A. B.; Harbs, R. M. P. Composto orgânico na produção de mudas de aroeira-vermelha. Scientia Agricola, v.9, p.27-33, 2008. http://dx.doi.org/10.5380/ rsa.v9i1.9898

Carvalho Filho, J. L. S.; Arrigoni-Blank, M. F.; Blank, A. F.; Santos Neto, A. L.; Amâncio, V. F. Produção de mudas de Cassia grandis L. em diferentes ambientes, recipientes e misturas de substratos. Revista Ceres, v.40, p.341-352, 2002.

Cunha, A. M.; Cunha, G. M.; Sarmento, R. A.; Cunha, G. M.; Amaral, J. F. T. Efeito de diferentes substratos sobre o desenvolvimento de mudas de Acacia sp. Revista Árvore, v.30, p.207-214, 2006. http:// dx.doi.org/10.1590/S0100-67622006000200007

Dantas, B. F.; Lopes, A. P.; Silva, F. F. S.; Lúcio, A. A.; Batista, P. F.; Pires, M. M. M. L.; Aragão, C. A. Taxas de crescimento de mudas de catingueira submetidas a diferentes substratos e sombreamentos. Revista Árvore, v.33, p.413-423, 2009. http://dx.doi.org/10.1590/ S0100-67622009000300003

Ferreira, D. F. Sisvar: A guide for its bootstrap procedures in multiple comparisons. Ciência e Agrotecnologia, v.38, p.109-112, 2014. http://dx.doi.org/10.1590/S1413-70542014000200001

Gomes, J. M.; Couto, L.; Leite, H. G.; Xavier, A.; Garcia, S. L. R. Crescimento de mudas de Eucalyptus grandis em diferentes tamanhos de tubetes e fertilização N-P-K. Revista Árvore, v.27, p.113127, 2003. http://dx.doi.org/10.1590/S0100-67622003000200001

Gomes J. M.; Paiva, H. N. Viveiros florestais. 3.ed. Viçosa: UFV, 2004. $116 \mathrm{p}$.

Köppen, W. Grundriss der klimakunde. ed. Berlin: Walter de Guyter, 1931.390p.

Lins, C. E. L.; Maia, L. C.; Cavalcante, U. M. T.; Sampaio, E. V. S. B. Efeito de fungos micorrízicos arbusculares no crescimento de mudas de Leucaena leucocephala (Lam.) De Wit. em solos de caatinga sob impacto de mineração de cobre. Revista Árvore, v.31, p.355-363, 2007. http://dx.doi.org/10.1590/S0100-67622007000200019

Nóbrega, R. S. A.; Ferreira, P. A. A.; Santos, J. G. D.; Boas, R. C. V.; Nóbrega, J. C. A.; Moreira, F. M. S. Substratos para o crescimento de mudas de Trema micrantha (L.) Blumes. Revista Brasileira de Ciências Agrárias, v.5, p.392-397, 2010. http://dx.doi:10.5039/ agraria.v5i3a708

Nóbrega, R. S. A.; Vilas Boas, R. C.; Nóbrega, J. C. A.; Moreira, F. M. S. Efeito do composto de lixo urbano no crescimento inicial de mudas de Enterolobium contortisiliquum (Vell.) Morong. Scientia Forestalis, v.36, p.181-189, 2008.

Paiva, E. P; Maia, S. S. S.; Cunha, C. S. M.; Coelho, M. F. B.; Silva, F. N. Composição do substrato para o desenvolvimento de mudas de manjericão (Ocimum basilicum L.). Revista Caatinga, v.24, p.62-67, 2011. 
Paiva Sobrinho, S.; Luz, P. B.; Silveira, T. L.S.; Ramos, D. T.; Neves, L. G.; Barelli M. A. A. Substratos na produção de mudas de três espécies arbóreas do cerrado. Revista Brasileira de Ciências Agrárias, v.5, p.238-243, 2010. http://dx.doi: 10.5039/agraria. v5i2a741

SiBCS - Sistema Brasileiro de Classificação de Solos. 3. ed. Rio de Janeiro: Empresa Brasileira de Pesquisa Agropecuária. Centro Nacional de Pesquisa em Solos. 2013. 353p.
Teles, M. M.; Alves, A. A.; Oliveira, J. C. G.; Bezerra, A. M. E. Métodos para a quebra da dormência em sementes de leucena (Leucaena leucocephala (Lam.) de Wit). Revista Brasileira de Zootecnia, v.29, p.387-391, 2000. http://dx.doi.org/10.1590/ S1516-35982000000200010

Viana, T. V. A.; Vasconcelos, D. V.; Azevedo, B. M.; Souza, V. F. Estudo da aptidão agroclimática do Estado do Piauí para o cultivo da aceroleira. Revista Ciência Agronômica, v.33, p.5-12, 2002. 